\title{
PENGARUH PROFITABILITAS, OPINI AUDITOR, DAN STRUKTUR KEPEMILIKAN TERHADAP KETEPATAN WAKTU PENYAMPAIAN LAPORAN KEUANGAN
}

\author{
Indah Suryani ${ }^{1}$ Dahlia Pinem ${ }^{2}$ \\ a[Universitas Pembangunan Nasional "Veteran" Jakarta \\ Indahsuryani056@gmail.com \\ b[Universitas Pembangunan Nasional "Veteran" Jakarta \\ pinem dahlia@yahoo.com
}

\begin{tabular}{ll}
\hline INFO ARTIKEL & ABSTRAK/ABSTRACK \\
\hline Histori Artikel : - & \multicolumn{1}{c}{ State revenue from the taxation sector remains } \\
Tgl. Masuk : - & dominating over This research is conducted to test the effect of \\
Tgl. Diterima : - & variables Profitability, Audit Opinion, and Ownership Structure \\
of the Timeliness of Financial Statement in the all companies & Infrastructure, Utilities, and Transportation sectors listed in \\
Tersedia Online : 19 desember & Indonesia Stock Exchange during 2013-2016. The population in \\
\hline Keywords: & this study amounted to 60 companies. Samples were obtained \\
The Profitability, Audit Opinion, & in this study amounted to 38 samples are selected by purposive \\
Ownership Structure, Timeliness & sampling method. The analysis technique used here is logistic \\
of Financial Statement & regression and hypothesis test using t-satistic with level of \\
& significance 5\%. The results indicate that the variable \\
Profitability not significant effect of the Timeliness of Financial & Statement and variable Ownership Structure not significant \\
effect of the Timeliness of Financial Statement. However, \\
variable Audit Opinion significant effect of the Timeliness of \\
Financial Statement
\end{tabular}

\section{PENDAHULUAN}

Laporan keuangan merupakan catatan informasi keuangan suatu perusahaan pada suatu periode akuntansi yang dapat digunakan untuk menggambarkan kinerja perusahaan tersebut yang merupakan bagian dari proses pelaporan keuangan. Ketepatan waktu pelaporan keuangan merupakan karakteristik penting bagi laporan keuangan, artinya informasi laporan keuangan harus disampaikan sebelum batas waktu yang diberikan sebagai acuan bagi perusahaan dalam pengambilan keputusan. Informasi pada laporan keuangan dikatakan relevan jika informasi tersebut disampaikan secara tepat waktu dan memiliki manfaat bagi pemakai informasi, sedangkan informasi keuangan dikatakan tidak relevan apabila terjadi penundaan dalam penyampaian laporan keuangan. Sehingga penyampaian pelaporan keuangan dapat mempengaruhi relevansi informasi keuangan yang disajikan dikarenakan ketepatwaktuan. Perusahaanperusahaan yang sudah go publik memiliki kewajiban untuk menyusun laporan keuangan dalam setiap periode. Perusahaan go public di Indonesia saat ini mengalami perkembangan yang pesat. Setiap perusahaan yang go public diwajibkan untuk menyampaikan laporan keuangan yang disusun sesuai dengan Standart Akuntansi Keuangan dan telah diaudit oleh akuntan publik yang terdaftar di Badan Pengawas Pasar Modal (BAPEPAM). Karena salah satu cara bagi investor untuk memantau kinerja perusahaan go publik adalah melalui laporan keuangan. Ketepatan waktu penyampaian laporan keuangan telah diatur oleh Bapepam dan Lembaga Keuangan Nomor KEP-346/BL/2011 dalam UU No 8 tentang pasar modal. Bahwa diatur oleh bapepam, perusahaan go public wajib menyampaikan laporan keuangan paling lambat pada akhir bulan ketiga (90 hari) 
setelah tanggal laporan keuangan tahunan paling sedikit 2 (dua) lembar, satu diantaranya dalam bentuk asli, dan disertai dengan laporan dalam salinan elektronik (soft copy).

Untuk variabel profitabilitas, PT. Adi Sarana Armada Tbk. (ASSA) mengalami kenaikan dari tahun 2015 sampai dengan tahun 2016 sebesar 1,18\% menjadi 2,05\%. Terjadinya kenaikan profitabilitas pada tahun 2015 ke tahun 2016 sehingga PT. Adi Sarana Armada Tbk. (ASSA) tidak dapat menyampaikan laporan keuangannya secara tepat waktu. Seharusnya PT. Adi Sarana Armada Tbk. (ASSA) cenderung menyampaikan laporan keuangan secara tepat waktu akan tetapi kenyataannya berbeda, perusahaan ini tidak dapat menyampaikan laporan keuangan secara tepat waktu. PT. Adi Sarana Armada Tbk. (ASSA) mendapatkan opini wajar. Akan tetapi PT. Adi Sarana Armada Tbk. (ASSA) tidak dapat menyampaikan laporan keuangannya secara tepat waktu. Menurut Hilmi \& Ali (2008) bahwa perusahaan yang mendapatkan opini wajar dari auditor untuk laporan keuangannya cenderung akan lebih tepat waktu dalam menyampaikan laporan keuangannya. Untuk variabel struktur kepemilikan, PT. Adi Sarana Armada Tbk. (ASSA) memiliki saham investor institusi sebesar Rp. 1,701,880,000 dari total saham yang beredar sebesar $\mathrm{Rp}$. 3,397,500,000 maka presentase kepemilikan institusional atas saham PT. Adi Sarana Armada Tbk. (ASSA) adalah 50,09\%. Tetapi kenyataannya PT. Adi Sarana Armada Tbk. (ASSA) memiliki presentase kepemilikan institusional $50,09 \%$ tidak menyampaikan laporan keuangannya dengan tepat waktu, padahal menurut teori yang ada bahwa perusahaan yang memiliki kepemilikan instisusional diatas $50 \%$ cenderung lebih cepat dalam menyampaikan laporan keuangan.

Beberapa penelitian terkait dengan ketepatan waktu penyampaian laporan keuangan telah dilakukan oleh penelitipeneliti sebelumnya. Penelitian Hilmi \& Ali (2008), Azizah,dkk (2016), dan Owusu \& Ansah (2000) yang menunjukan bahwa tingkat profitabilitas perusahaan mempengaruhi ketepatan waktu penyampaian laporan keuangan. Sebaliknya penelitian berbeda dengan penelitian yang dilakukan oleh Iyoha (2012), Riswan \& Saputri (2015), dan Kadir (2011) yang menyatakan bahwa profitabilitas tidak berpengaruh terhadap ketepatan waktu penyampaian laporan keuangan. Penelitian yang telah dilakukan oleh Dewi \& Pamudji (2013), Hastutik (2015), dan Daoud et.al (2014) menunjukan bahwa opini auditor mempengaruhi ketepatan waktu penyampaian laporan keuangan. Sebaliknya penelitian berbeda dengan penelitian yang dilakukan oleh Henisa (2015), Dewi \& Jusia (2013), dan Imaniar \& Kurnia (2016) yang menyatakan bahwa opini auditor tidak berpengaruh terhadap ketepatan waktu penyampaian laporan keuangan. Penelitian yang telah dilakukan oleh Sanjaya \& Wirawati (2016) dan Astuti (2007) menunjukan bahwa struktur kepemilikan mempengaruhi ketepatan waktu penyampaian laporan keuangan. Sebaliknya penelitian berbeda dengan penelitian yang dilakukan oleh Hastutik (2015) dan Mouna \& Anis (2013) yang menyatakan bahwa struktur kepemilikan tidak berpengaruh terhadap ketepatan waktu penyampaian laporan keuangan.

Bedasarkan pada fenomena dan penelitian-penelitian sebelumnya, masih terdapat keterbatasan dan tidak konsistennya hasil penelitian. Hal ini yang menjadikan penulis tertarik untuk melakukan penelitian mengenai ketepatan waktu penyampaian laporan keuangan. Tujuan dalam penelitian ini untuk menguji apakah profitabilitas, opini auditor, dan struktur kepemilikan terhadap ketepatan waktu penyampaian laporan keuangan.

\section{KERANGKA TEORI DAN PENGEMBANGAN HIPOTESIS}

\section{Teori Keagenan (Agency Theory)}

Teori keagenan menjelaskan hubungan antara agen dan prinsipal, agen sebagai pihak manajemen seringkali mempunyai tujuan yang berlawanan dengan tujuan prinsipal untuk memaksimalkan kekayaan para pemegang saham. Dijelaskan dalam teori agensi sering munculnya ketidakseimbangan 
informasi antara agent dan principal di dalam suatu organisasi. Untuk menekan ketidakseimbangan informasi tersebut dapat dilakukan dengan adanya peraturan yang mewajibkan perusahaan untuk menyampaikan laporan keuangan secara tepat waktu. Dengan mewajibkan setiap perusahaan untuk menyampaikan informasi keuangan secara tepat waktu maka akan mengurangi munculnya ketidakseimbangan informasi (Imaniar \& Kurnia, 2016).

\section{Teori Kepatuhan (Compliance Theory)}

\begin{abstract}
Kepatuhan merupakan sifat patuh dan taat terhadap peraturan. Kepatuhan merupakan motivasi seseorang, kelompok, atau organisasi untuk berbuat atau tidak berbuat sesuatu dengan aturan yang telah ditetapkan (Rahmawati, 2012, hlm.157). Menurut teori kepatuhan (Compliance), perusahaan harus menjadi penduduk yang baik atau "good citizen" yang mematuhi semua peraturan yang berlaku seperti kode etik perusahaan, profesi, UU, aturan pemerintah, hukum, dan lain sebagainya (Harahab, 2011 hlm. 608). Keterkaitan teori kepatuhan dengan ketepatan waktu penyampaian laporan keuangan yaitu bahwa perusahaan diharuskan menyampaikan laporan keuangan secara tepat waktu sesuai dengan Keputusan Ketua Bapepam dan Lembaga Keuangan Nomor: KEP-346/BL/2011 tanggal 5 Juli 2011.
\end{abstract}

\section{Pengaruh Profitabilitas terhadap Ketepatan Waktu Penyampaian Laporan Keuangan}

Profitabilitas menggambarkan besar kecilnya kemampuan perusahaan dalam menghasilkan laba. Profitabilitas dapat diukur menggunakan Return On Asset (ROA) yaitu dengan membagi laba tahun berjalan dengan total aset. Profitabilitas yang tinggi merupakan kabar baik bagi perusahaan, artinya mampu menunjukkan kinerja perusahaan dalam menghasilkan laba. Profitabilitas dapat mempengaruhi ketepatan waktu penyampaian laporan keuangan. Menurut Owusu \& Ansah (2000) dan Azizah, dkk (2016) menunjukkan bahwa profitabilitas mempunyai pengaruh terhadap ketepatan waktu penyampaian laporan keuangan. Semakin tinggi tingkat profitabilitas maka perusahaan menyampaikan laporan keuangan dengan tepat waktu.

H1 : Profitabilitas berpengaruh terhadap ketepatan waktu penyampaian laporan keuangan.

\section{Pengaruh Opini Auditor terhadap Ketepatan Waktu Penyampaian Laporan keuangan}

Opini auditor yang merupakan tanggung jawab akuntan publik, dimana akuntan publik memberikan pendapat-nya terhadap kewajaran laporan keuangan yang disusun oleh manajemn dan merupakan tanggung jawab manajemen dijelaskan dalam Agoes, Sukrisno (2012, hlm. 74). Opini auditor menggambarkan kewajaran atas informasi laporan keuangan. Opini auditor dapat mempengaruhi ketepatan waktu penyampaian laporan keuangan. Perusahaan yang mendapatkan opini wajar tanpa pengecualian (unqualified opinion) cenderung akan menyampaikan laporan keuangan dengan tepat waktu, artinya perusahaan tidak menunda untuk menyampaikan kabar baik (good news) tentang kewajaran laporan keuangan. Perusahaan yang mendapatkan selain opini wajar tanpa pengecualian (unqualified opinion) cenderung men-unda menyampaikan laporan keuangan, artinya perusahaan memperlambat untuk penyampaian laporan keuangan karena opini yang tidak menyenangkan atau berisi berita buruk (bad news). Menurut Dewi \& Pamudji (2013) menunjukkan bahwa Perusahaan yang mendapatkan unqualified opinion dari auditor untuk laporan keuangannya berpengaruh signifikan terhadap ketepatan waktu penyampaian laporan keuangan. Hal ini menunjukkan bahwa opini unqualified opinion dari KAP mendorong perusahaan lebih cepat menyampaikan laporan keuangannya, karena manajemen melihat bahwa hasil opini audit unqualified opinion sebagai sebuah opini yang baik atas kewajaran laporan keuangan perusahaan. 
H2 : Opini Auditor berpengaruh terhadap ketepatan waktu penyampaian laporan keuangan.

\section{Pengaruh Struktur Kepemilikan terhadap Ketepatan Waktu Penyampaian Laporan Keuangan}

Struktur kepemilikan memiliki pengaruh terhadap perusahaan sebagai pemegang saham terbesar di dalam perusahaan. Kepemilikan saham terhadap perusahaan memiliki 2 (dua) aspek yang berhubungan dengan pihak dalam atau manajemen perusahaan dan pihak luar perusahaan. Struktur kepemilikan diproksikan dengan kepemilikan institusional dapat diukur dengan membagi jumlah saham institusi dengan jumlah saham yang beredar. Investor memiliki peran dalam perusahaan dalam hal pengawasan terhadap keputusan yang diambil manajemen karena pendanaan perusahaan sebagian besar berasal dari investor. Menurut Choiruddin (2015) menyatakan bahwa kepemilikan perusahaan oleh pihak luar mempunyai kekuatan yang besar dalam mempengaruhi perusahaan melalui media masa berupa kritikan atau komentar yang semuanya dianggap suara masyarakat. Adanya konsentrasi kepemilikan pihak luar menimbulkan pengaruh dari pihak luar sehingga mengubah pengelolaan perusahaan yang semula berjalan sesuai keinginan perusahan itu sendiri menjadi memiliki keterbatasan. Sehingga pihak luar dapat menekankan manajemen untuk cepat dalam menyampaikan laporan keuagan. Struktur kepemilikan berpengaruh terhadap ketepatan waktu penyampaian laporan keuangan.

H3 : Struktur Kepemilikan berpengaruh terhadap ketepatan waktu penyampaian laporan keuangan.

\section{METODE PENELITIAN}

\section{Populasi, Sampel, dan Teknik Pengambilan Sampel}

Dalam penelitian ini yang dijadikan populasi adalah perusahaan jasa yang terdaftar di Bursa Efek Indonesia (BEI) dan sampel yang digunakan adalah perusahaan jasa sektor infrastruktur, utilitas, dan transportasi yang terdaftar di Bursa Efek Jakarta (BEI) secara berturut- turut selama periode 2013-2016. Metode pengambilan sampel yang digunakan adalah metode purposive sampling yaitu menentukan sampel dengan memenuhi kriteria tertentu, adapun kriteria yang digunakan dalam penentuan sampel adalah sebagai berikut:

a. Perusahaan jasa Infrastruktur, Utilitaas, dan Transportasi yang terdaftar di Bursa Efek Indonesia (BEI) secara berturut-turut selama periode 2013 sampai 2016 yang menerbitkan laporan keuangan yang telah diaudit dan dipublikasikan.

b. Perusahaan yang telah diaudit dan memiliki data tanggal penyampaian laporan keuangan audited ke Otoritas Jasa Keuangan (OJK) untuk periode 2013-2016.

\section{Definisi Operasional Variabel}

a. Ketepatan Waktu Penyampaian Laporan Keuangan (Y)

Variabel dependen dalam penelitian ini adalah Ketepatan Waktu Penyampaian Laporan Keuangan (timeliness). Ketepatanwaktuan dapat diartikan sebagai informasi laporan keuangan yang disajikan secepat mungkin untuk membantu perusahaan dalam pengambilan keputusan sebelum infromasi tersebut kehilangan kekuatan untuk mempengaruhi keputusan (Suwardjono, $2010 \mathrm{hlm}$. 170).

b. Profitabilitas

Profitabilitas merupakan kemampuan suatu perusahaan dalam menghasilkan laba (Murhadi, 2013 hlm. 63).

c. Opini Auditor (X2)

Opini auditor yang merupakan tanggung jawab akuntan publik, dimana akuntan publik memberikan pendapatnya terhadap kewajaran laporan keuangan yang disusun oleh manajemen dan merupakan tanggung 
jawab manajemen (Agoes, $2012 \mathrm{hlm}$. 74).

d. Struktur Kepemilikan

Struktur kepemilikan yang diproksikan dengan kepemilikan institusional merupakan kepemilikan oleh investor besar seperti usaha reksa dana dan dana pension, yang membeli saham korporasi dalam volume besar (Griffin \& Elbert, 2015 hlm. 98).

\section{Pengukuran Variabel}

a. Ketepatan Waktu Penyampaian Laporan Keuangan (Y)

Ketepatan waktu penyampaian laporan keuangan diukur menggunakan skala dummy dengan kategori 1 untuk perusahaan yang menyampaikan laporan keuangannya dengan tepat waktu (menyampaikan laporan keuangannya kurang dari 90 hari setelah tanggal laporan keuangan) dan kategori 0 untuk perusahaan yang menyampaikan laporan keuangannya tidak tepat waktu atau terlambat (manyampaikan laporan keuangannya lebih dari 90 hari setelah tanggal laporan keuangan) untuk periode 20132016.

b. Profitabilitas

Variabel profitabilitas menggunakan skala rasio dan satuan datanya adalah desimal. Yang diukur dengan membandingkan antara laba tahun berjalan dengan total aset. Rumus:

$\begin{array}{rc}\text { Return On } & \begin{array}{c}\text { Earning After } \\ \text { Taxes }\end{array} \\ \text { Asset }(\text { ROA }) & =\frac{100 \%}{\text { Total Asset }}\end{array}$

c. Opini Auditor

Variabel ini menggunakan variabel dummy. Kategori perusahaan yang mendapat opini wajar tanpa pengecualian dari auditor diberi nilai dummy 1 dan kategori perusahaan yang mendapat opini selain wajar tanpa pengecualian diberi nilai dummy 0 . Data diperoleh dari laporan keuangan perusahaan pada bagian laporan audit, seperti:

\begin{tabular}{lll}
\hline 1 & Opini Wajar Tanpa Pengecualian & 1 \\
\hline 2 & $\begin{array}{l}\text { Opini Wajar Tanpa Pengecualian } \\
\text { dengan Bahasa Penjelasan }\end{array}$ & 0 \\
\hline 3 & Opini Wajar dengan Pengecualian & 0 \\
\hline 4 & Opini Tidak Wajar & 0 \\
\hline 5 & $\begin{array}{l}\text { Pernyataan tidak Memberikan } \\
\text { Pendapat }\end{array}$ & 0 \\
\hline
\end{tabular}

Tabel 1 Opini Auditor

d. Struktur Kepemilikan (X3)

Variabel Struktur Kepemilikan yang diproksikan dengan kepemilikan institusional diatas 50\% menggunakan skala rasio dan satuan datanya adalah desimal. Yang diukur dengan membandingkan antara jumlah saham institusi dengan jumlah saham yang beredar. Rumus :

Jumlah Saham

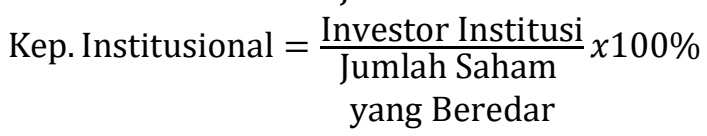

\section{HASIL DAN PEMBAHASAN}

Penelitian ini menggunakan data perusahaan jasa sektor infrastruktur, utilitas, dan transportasi selama 4 tahun dari periode 2013-2016 dengan jumlah perusahaan sebanyak 60. Sampel data yang dipilih dalam penelitian ini adalah data yang diperoleh dari laporan keuangan perusahaaan. Berdasarkan proses seleksi sampel yang dilakukan dengan kriteria yang telah ditentukan, maka diperoleh 38 perusahaan yang akan dijadikan sampel dengan jumlah tahun pengamatan dari tahun 2013-2016, sehingga total sampel yang diperoleh sebanyak 152 sampel.

\section{ANALISIS DATA}

Pengujian hipotesis dalam penelitian ini dilakukan dengan menggunakan analisis regresi logistik. Alasan penggunaan analisis regresi logistik karena variabel independen dalam penelitian ini merupakan variabel kategorikal (non-metrik). Analisis regresi logistik tidak memerlukan uji normalitas data pada variabel bebasnya (Ghozali 2011, hlm. 321). 
Uji Multikolinearitas

Uji Multikolonieritas bertujuan untuk menguji apakah model regresi ditemukan adanya kolerasi antar variabel bebas (independen).

Tabel 1. Hasil Uji Multikolinearitas

\begin{tabular}{llll}
\hline \multirow{2}{*}{ Model } & \multicolumn{2}{c}{ Collinearity Statistics } \\
\cline { 2 - 4 } & \multicolumn{2}{c}{ Tolerance } & VIF \\
\hline \multirow{3}{*}{1} & (Constant) & & \\
\cline { 2 - 4 } & Profitabilitas & 0.942 & 1.062 \\
\cline { 2 - 4 } & Opini Auditor & 0.941 & 1.063 \\
\cline { 2 - 4 } & $\begin{array}{l}\text { Struktur } \\
\text { Kepemilikan }\end{array}$ & 0.999 & 1.001 \\
\hline
\end{tabular}

Tabel 2. Hasil Uji Multikolinearitas

Dari tabel 2 di atas, dapat disimpulkan bahwa tidak ada satu variabel independen yang memiliki tolerance value $<0,1$ dan Variance Inflation Factor (VIF) > 10. Jadi dapat disimpulkan bahwa tidak terjadi multikolinearitas antar variabel independen.

\section{PENGUJIAN HIPOTESIS}

Berdasarkan uji koefisien determinasi (Nagelkerke's $R$ square) dapat dilihat bahwa nilai Nagelkerke $R$ Square sebesar 0,072. Hal ini menunjukkan bahwa variabel independen dalam penelitian ini, yaitu Profitabilitas, Opini Auditor, dan Struktur Kepemilikan dapat menjelaskan variabel dependen yaitu Ketepatan Waktu Penyampaian Laporan Keuangan sebesar 0,072 (7,2\%).

Berdasarkan uji kelayakan model regresi diperoleh nilai Chi-square sebesar 6,142 dengan nilai signifikansi sebesar 0,631 lebih besar dari taraf signifikansi sebesar 0,05 $(0,631>0,05)$, hal ini berarti hipotesis nol $\left(\mathrm{H}_{0}\right)$ diterima dan model mampu memprediksi nilai observasinya atau dapat dikatakan cocok dengan data observasinya. Maka model regresi logistik dapat digunakan untuk analisis selanjutnya.

Berdasarkan uji keseluruhan model, model penelitian ini dinyatakan fit dengan data, artinya dengan menambahkan variabel Profitabilitas, Opini Auditor, dan Struktur Kepemilikan akan memperbaiki model regresi atau berarti model fit dengan data karena memiliki nilai -2LL awal dengan nilai -2LL akhir yang menurun.
Tabel 2. Hasil Uji Parsial (Uji t)

Variables in the Equation

\begin{tabular}{cccccccc}
\hline & & & & & & \multicolumn{2}{c}{$\operatorname{Exp}(B$} \\
& & B & S.E. & Wald & df & Sig. & ) \\
\hline \multirow{3}{*}{$\begin{array}{c}\text { Step } \\
1^{\mathrm{a}}\end{array}$} & PRO & -.131 & .963 & .019 & 1 & .892 & .877 \\
\cline { 2 - 8 } & OA & 1.010 & .368 & 7.520 & 1 & .006 & 2.745 \\
\cline { 2 - 8 } & SK & -.608 & .968 & .380 & 1 & .538 & .545 \\
\cline { 2 - 8 } & Constant & .244 & .724 & .113 & 1 & .737 & 1.276 \\
\hline
\end{tabular}

a. Variable(s) entered on step 1: PRO, OA, SK.

Tabel 3. Hasil Uji Parsial (Uji t)

Berdasarkan tabel 3 di atas, nilai statistik wald untuk variabel Profitabilitas adalah sebesar 0,019 sedangkan dari tabel Chi- Square untuk tingkat signifikansi $5 \%$ atau 0,05 dan derajat bebas $=1$ diperoleh hasil 3,841. Nilai probabilitas (sig) profitabilitas sebesar 0,892 dimana lebih besar dari tingkat signifikansi 0,05. Hasil menunjukan bahwa wald hitung < ChiSquare tabel yaitu 0,019<3,841 dan nilai signifikansi sebesar 0,892 >0,05. Hal ini berarti bahwa hipotesis pertama $\left(\mathrm{H}_{1}\right)$ dalam penelitian ini ditolak sehingga dapat disimpulkan bahwa Profitabilitas tidak berpengaruh terhadap Ketepatan Waktu Penyampaian Laporan Keuangan.

Statistik wald untuk variabel Opini Auditor adalah sebesar 7,520 sedangkan tabel Chi-Square untuk tingkat signifikansi $5 \%$ atau 0,05 dan derajat bebas $=1$ diperoleh hasil 3,841. Nilai probabilitas (sig) Opini Auditor sebesar 0,006 dimana lebih kecil dari tingkat signifikansi 0,05 . Hasil menunjukan bahwa wald hitung $>$ Chi-Square tabel yaitu 7,520 > 3,841 dan nilai signifikansi sebesar 0,006 $<0,05$. Hal ini berarti bahwa hipotesis kedua $\left(\mathrm{H}_{2}\right)$ dalam penelitian ini dapat diterima sehingga dapat disimpulkan bahwa Opini Auditor berpengaruh terhadap Ketepatan Waktu Penyampaian Laporan Keuangan.

Statistik wald untuk variabel Struktur Kepemilikan adalah sebesar 0,380 sedangkan tabel Chi-Square untuk tingkat signifikansi 5\% atau 0,05 dan derajat bebas $=1$ diperoleh hasil 3,841. Nilai probabilitas (sig) struktur kepemilikan sebesar 0,538 dimana lebih besar dari tingkat signifikansi 0,05. Hasil menunjukan bahwa wald hitung < Chi-Square tabel yaitu $0,380<3,841$ dan nilai signifikansi sebesar 0,538 $>0,05$. Hal ini berarti bahwa hipotesis ketiga $\left(\mathrm{H}_{3}\right)$ dalam penelitian ini ditolak sehingga dapat disimpulkan bahwa Struktur Kepemilikan tidak 
berpengaruh terhadap Ketepatan Waktu Penyampaian Laporan Keuangan.

\section{Model Regresi}

Bedasarkan tabel 2, dapat dilihat bahwa nilai konstanta 0,244, koefisien Profitabilitas sebesar $-0,131$, koefisien Opini Auditor (OA) sebesar 1,010 , dan koefisen Struktur Kepemilikan (SK) sebesar $-0,608$. Sehingga persamaan regresi logistik yang terbentuk adalah sebagai berikut:

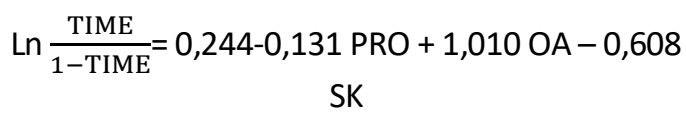

Berdasarkan persamaan regresi logistik diatas dapat diartikan bahwa nilai konstanta sebesar 0,244 lebih besar dari nilai probabilitas 0. Sehingga dapat disimpulkan bahwa kemungkinan perusahaan melakukan ketepatan waktu dalam penyampaian laporan keuangan besar. Nilai konstanta sebesar 0,244 artinya kemungkinan perusahaan akan meyampaikan laporan keuangan secara tepat waktu akan meningkat

Variabel profitabilitas diukur dengan membandingkan laba tahun berjalan dengan Total Aset mempunyai koefisien negatif sebesar 0,131 , yang berarti setiap kenaikan $1 \%$ pada Profitabilitas akan menurunkan kemungkinan ketepatan waktu penyampaian laporan keuangan sebesar 0,131 dengan asumsi variabel lain konstan atau sama dengan nol (0).

Variabel opini audit mempunyai koefisien positif sebesar 1,010, jika opini audit wajar tanpa pengecualian maka kemungkinan ketepatan waktu penyampaian laporan keuangannya besar.

Variabel Struktur Kepemilikan yang diproksikan dengan kepemilikan institusional menggunakan perbandingan jumlah saham institusi dengan jumlah saham yang beredar mempunyai koefisien negates sebesar 0,608 yang berarti setiap penurunan jumlah saham pada Stuktur Kepemilikan akan menaikan kemungkinan ketepatan waktu pelaporan keuangan sebesar 0,608 dengan asumsi variabel lain konstan atau sama dengan nol (0).

\section{PEMBAHASAN}

\section{a. Pengaruh Profitabilitas terhadap Ketepatan Waktu Penyampaian Laporan Keuangan}

Hasil uji regresi logistik pada variabel Profiabilitas diukur menggunakan ROA menunjukkan bahwa nilai statistik wald sebesar 0,019 sedangkan dari tabel Chi- Square untuk tingkat signifikansi $5 \%$ atau 0,05 dan derajat bebas $=1$ diperoleh hasil 3,841. Nilai probabilitas (sig) opini audit sebesar 0,892 dimana lebih besar dari tingkat signifikansi 0,05. Hasil menunjukan bahwa wald hitung < ChiSquare tabel yaitu $0,019<3,841$ dan nilai signifikansi sebesar 0,892 >0,05. Hal ini berarti bahwa hipotesis pertama $\left(\mathrm{H}_{1}\right)$ dalam penelitian ini dapat ditolak sehingga dapat disimpulkan bahwa Profitabilitas tidak berpengaruh terhadap Ketepatan Waktu Penyampaian Laporan Keuangan.

Nilai Profitabilitas yang dimiliki perusahaan yang tinggi belum tentu tepat waktu dalam menyampaikan laporan keuangannya, demikian juga sebaliknya perusahaan yang memiliki nilai Profitabilitas yang rendah belum tentu tidak tepat waktu dalam menyampaikan laporan keuangan. Tidak ditemukannya pengaruh profitabilitas karena kemungkinan ketepatan waktu penyampaian laporan keuangan tidak hanya melihat dari kemampuan perusahaan menghasilkan laba, namun juga dipengaruhi oleh faktor-faktor lainnya.

Penelitian membuktikan bahwa ketepatan waktu penyampaian laporan keuangan tidak dipengaruhi oleh variabel profitabilitas, jika dilihat dari nilai rata-rata (mean) diketahui bahwa profitabilitas yang diukur dengan menggunakan laba tahun berjalan dibagi dengan total aset mempunyai nilai yang mengalami kenaikan pada PT. Berlian Laju Tanker Tbk. (BLTA) pada tahun 2014, 2015, dan 2016 dengan menghasilkan Return On Assets (ROA) sebesar -0,0582 (-5,82\%), 0,0019 (0,19\%), dan 0,1553 (15,53\%). Meskipun perusahaan tersebut memperoleh peningkatan dalam menghasilkan laba namun PT. Berlian Laju Tanker Tbk. (BLTA) tersebut tetap tidak tepat waktu dalam menyampaikan laporan keuangan. Hal ini dapat disebabkan karena kemampuan perusahaan dalam menghasilkan laba yang kurang karena ada faktor yang 
menghambat perusahaan untuk memberikan mutu yang baik bagi investor.

Hasil penelitian ini mendukung hipotesis yang membuktikan tidak adanya pengaruh Profitabilitas terhadap Ketepatan Waktu Penyampaian Laporan Keuangan, bahwa suatu perusahaan yang mempunyai kemampuan dalam menghasilkan laba yang tinggi belum tentu tepat waktu dalam menyampaikan laporan keuangannya, demikian juga sebaliknya belum tentu perusahaan yang tidak mempunyai kemampuan dalam menghasilkan laba tidak tepat waktu dalam menyampaikan laporan keuangan. Hal ini sejalan dengan penelitian yang dilakukan Iyoha (2012), Riswan \& Saputri (2015), dan Kadir (2011) yang menyatakan bahwa Profitabilitas tidak berpengaruh terhadap Ketepatan Waktu Penyampaian Laporan Keuangan.

\section{b. Pengaruh Opini Auditor terhadap Ketepatan Waktu Penyampaian Laporan Keuangan}

Hasil uji regresi logistik pada variabel Opini Audit (OA) diukur menggunakan variabel dummy menunjukkan bahwa nilai statistik wald sebesar 7,520 sedangkan dari tabel Chi- Square untuk tingkat signifikansi 5\% atau 0,05 dan derajat bebas $=1$ diperoleh hasil 3,841. Nilai probabilitas (sig) opini audit sebesar 0,006 dimana lebih kecil dari tingkat signifikansi 0,05. Hasil menunjukan bahwa wald hitung > ChiSquare tabel yaitu 7,520 > 3,841 dan nilai signifikansi sebesar $0,006<0,05$. Hal ini berarti bahwa hipotesis pertama $\left(\mathrm{H}_{2}\right)$ dalam penelitian ini dapat diterima sehingga dapat disimpulkan bahwa Opini Audit berpengaruh terhadap Ketepatan Waktu Penyampaian Laporan Keuangan.

Perusahaan yang mendapatkan opini wajar tanpa pengecualian maka kemungkinan perusahaan akan menyampaikan laporan keuangan secara tepat waktu. Sedangkan perusahaan yang memiliki opini selain wajar tanpa pengecualian maka perusahaan akan terlambat menyampaikan laporan keuangan secara tepat waktu. Hal ini sesuai dengan teori yang dikemukakan oleh Hilmi \& Ali (2008) menyatakan bahwa perusahaan yang mendapatkan unqualified opinion cenderung akan tepat waktu dalam menyampaikan laporan keuangannya dan cenderung tidak tepat waktu dalam menyampaikan laporan keuangannya apabila mendapat opini selain unqualified opinion. Hal ini didukung oleh fakta penelitian yaitu PT. Perusahaan Gas Negara (Persero) Tbk. (PGAS) pada tahun 2013 mendapatkan opini wajar tanpa pengecualian, dan menyampaikan laporan keuangannya secara tepat waktu. Hal ini dikarenakan menajemen tidak perlu melakukan penundaan penyampaian laporan keuangan apabila mendapat opini selain wajar tanpa pengecualian. Berbeda dengan yang terjadi di PT. Leyand International Tbk. (LAPD) pada tahun 2013 mendapatkan opini selain wajar tanpa pengecualian sehingga mengalami keterlambatan dalam menyampaikan laporan keuangan. Hal ini disebabkan menajemen berusaha untuk memperbaiki dan diperlukan negosiasi kepada auditor karena merupakan bad news bagi investor atau pihak yang berkepentingan sehingga menunda untuk penyampaian laporan keuangan.

Hasil penelitian ini mendukung hipotesis yang membuktikan pengaruh Opini Audit terhadap Ketepatan Waktu Penyampaian Laporan Keuangan, bahwa suatu perusahaan yang mendapat opini wajar tanpa pengecualian cenderung akan menyampaikan laporan keuangan secara tepat waktu. Hal ini sependapat dengan Dewi \& Pamudji (2013) menjelaskan bahwa opini wajar tanpa pengecualian yang diberikan oleh auditor mendorong perusahaan lebih cepat menyampaikan laporan keuangan karena opini yang diterima perusahaan wajar tanpa pengecuaian sebagai opini yang baik atas kewajaran laporan keuangan perusahaan.

Hasil penelitian ini konsisten dengan penelitian yang dilakukan oleh Dewi \& Pamudji (2013), Hastutik (2015), dan Daoud et.al (2014) yang menyatakan bahwa Opini Audit berpengaruh terhadap Ketepatan Waktu Penyampaian Laporan Keuangan.

\section{c. Pengaruh Struktur Kepemilikan terhadap Ketepatan Waktu Penyampaian Laporan Keuangan}

Pada variabel ketiga, hasil uji regresi logistik pada variabel Struktur Kepemilikan (SK) yang diproksikan dengan kepemilikan institusional 
menunjukan bahwa nilai statistik wald adalah sebesar 0,380 sedangkan tabel Chi-Square untuk tingkat signifikansi 5\% atau 0,05 dan derajat bebas $=1$ diperoleh hasil 3,841. Nilai probabilitas (sig) Ukuran Perusahaan sebesar 0,538 dimana lebih besar dari tingkat signifikansi 0,05 . Hasil menunjukan bahwa wald hitung < Chi-Square tabel yaitu 0,380 $<3,841$ dan nilai signifikansi sebesar 0,538>0,05. Ini menunjukan bahwa hipotesis ketiga $\left(\mathrm{H}_{3}\right)$ ditolak, sehingga dapat disimpulkan bahwa Struktur Kepemilikan tidak berpengaruh terhadap Ketepatan Waktu Penyampaian Laporan Keuangan.

Kepemilikan institusional tidak tidak berpengaruh terhadap ketepatan waktu penyampaian laporan keuangan karena konsentrasi kepemilikan yang menyebar dalam persentase yang kecil tersebut menyebabkan para pemegang saham kurang memiliki kekuatan dan pengaruh untuk mengawasi kinerja manajemen perusahaan. Namun begitu, ada sebagian kecil perusahaan dalam penelitian ini yang memiliki tingkat kepemilikan institusional yang tinggi maupun rendah tetap menyampaikan laporan keuangannya tepat waktu. Hal tersebut lebih disebabkan karena perusahaan-perusahaan tersebut memiliki mekanisme pengawasan yang baik dan sudah memiliki reputasi yang juga baik.

Hal ini didukung oleh fakta penelitian yaitu pada tahun 2016 perusahaan-perusahaan seperti PT. Indosat Tbk., PT. Arpeni Pratama Ocean Line Tbk., PT. Buana Listya Tama Tbk., dan PT. Humpuss Intermoda Transportasi Tbk. yang masing masing memiliki persentase kepemilikan institusional sebesar 79,29\%, $83,30 \%, 82,16 \%$, dan $78,36 \%$ tapi kenyataaanya perusahaan-perusahaan itu tidak menyampaikan laporan keuangannya tepat waktu. Sementara PT. Nusantara Infrastructure Tbk., PT. XL Axiata Tbk., PT. Logindo Samudra makmur Tbk., dan PT. Trada Maritime Tbk. yang masing-masing persentase kepemilikan institusionalnya hanya sebesar $43,33 \%, 39,86 \%$, $40,48 \%$, dan $35,82 \%$ menyampaikan laporan keuangannya tepat waktu. Ini mengindikasikan bahwa semakin kecil persentase kepemilikan institusional maka semakin besar probabilitas perusahaan tepat waktu.
Hasil penelitian ini mendukung hipotesis yang membuktikan tidak adanya pengaruh Struktur Kepemilikan terhadap Ketepatan Waktu Penyampaian Laporan Keuangan, bahwa suatu perusahaan yang memiliki kepemilikan institusional tinggi belum tentu tepat waktu dalam menyampaikan laporan keuangannya, demikian juga sebaliknya belum tentu perusahaan yang memiliki kepemilikan institusional tinggi rendah tidak tepat waktu dalam menyampaikan laporan keuangan. Hal ini sejalan dengan penelitian yang dilakukan Rianti (2014) dan Mouna \& Anis (2013) yang menyatakan bahwa Struktur Kepemilikan tidak berpengaruh terhadap Ketepatan Waktu Penyampaian Laporan Keuangan.

\section{KESIMPULAN}

Tujuan penelitian ini adalah untuk menguji apakah terdapat pengaruh Profitabilitas, Opini Auditor, Struktur Kepemilikan terhadap Ketepatan Waktu Penyampaian Laporan Keuangan. Dari hasil pengujian parsial ditemukan bahwa opini auditor berpengaruh signifikan terhadap terhadap ketepatan waktu penyampaian laporan keuangan, hal ini membuktikan bahwa perusahaan yang mendapat opini wajar tanpa pengecualian mempengaruhi ketepatan waktu penyampaian laporan keuangan. Sedangkan profitabilitas dan struktur kepemilikan tidak berpengaruh signifikan terhadap ketepatan waktu penyampaian laporan keuangan. Hasil pengujian koefisien determinasi bahwa Nagelkerke R Square variabel independen dalam penelitian ini, yaitu Profitabilitas, Opini Auditor, dan Struktur Kepemilikan dapat menjelaskan variabel dependen yaitu Ketepatan Waktu Penyampaian Laporan Keuangan sebesar 0,072 $(7,2 \%)$ sedangkan sisanya 0,928 (92,8\%) dijelaskan oleh faktor- faktor oleh variabel lain yang tidak dimasukkan kedalam penelitian ini atau faktor-faktor lain seperti Reputasi KAP, Solvabilitas, Leverage, Ukuran Perusahaan, Umur Perusahaan, Auditor Switching, dan lainlain.

\section{KETERBATASAN PENELITIAN}

Berdasarkan data yang diperoleh dari sumber yang digunakan, terdapat banyak Perusahaan melaporkan laporan keuangannya 
tidak berturut- turut selama periode pengamatan pada tahun 2013-2016 sehingga memperkecil jumlah sampel penelitian yang digunakan yaitu dari 60 perusahaan jasa sektor Infrastruktur, utilitas, dan transpotasi yang terdaftar di BEI menjadi sampel sebanyak 38 perusahaan dalam periode 2013-2016 dan tidak lengkapnya data tanggal penyampaian laporan keuangan yang diperoleh dari Bursa Efek Indonesia (BEI), sehingga terdapat 22 perusahaan sampel yang tidak bisa dipakai dalam penelitian ini.

\section{Kontribusi Praktis}

Penelitian ini diharapkan bagi peneliti selanjutnya dapat menggunakan faktor-faktor yang memengaruhi Ketepatan Waktu Penyampaian Laporan Keuangan lainya seperti Debt to Equity Ratio (DER), Umur Perusahaan, Ukuran Perusahaan, Reputasi KAP, dan faktor lainnya, diharapkan bagi investor dapat mempertimbangkan laporan keuangan perusahaan karena memiliki pengaruh besar bagi investor untuk mengetahui tepat atau tidak tepat waktu dalam menyampaikan laporan keuangan, terlebih lagi untuk membantu investor dalam pengambilan keputusan untuk bahan pertimbangan dalam berinvestasi, diharapkan bagi auditor dapat memberikan opini secara akurat terhadap perusahaan sehingga opini tersebut dapat dipertanggung jawabkan, dan diharapkan bagi perusahaan dapat memberikan informasi sebagai gambaran pentingnya penyampaian laporan keuangannya secara tepat waktu. Sehingga dapat menghasilkan laba yang tinggi, struktur kepemilikan yang tinggi dan juga perusahaan yang mendapatkan opini wajar tanpa pengecualian karena hal tersebut dapat mempengaruhi kualitas dari laporan keuangan yang dihasilkan.

\section{DAFTAR PUSTAKA}

Badan Pengawas Pasar Modal. (2011). Keputusan Ketua Badan Pengawas Pasar Modal dan Lembaga Keuangan, Nomor: KEP-346/PM/2011 tentang Laporan Tahunan Emiten Atau Perusahaan Publik.

Agoes, I. (2012). Auditing, Jakarta: Salemba Empat.
Azizah \& Nurhayati. (2016). 'Pengaruh tingkat profitabilitas dan tingkat likuiditas terhadap ketepatan waktu penyampaian laporan keuangan (timeliness) pada perusahaan manufaktur yang listing di bursa efek indonesia periode 2010-2014'. ISSN: 2460-6561.

Brigham, E., \& Houston, J. (2011). Essentials of financial management (dasar-dasar manajemen keuangan), Edisi 11. Jakarta: Salemba Empat.

Choiruddin. (2015).'Analisis faktor-faktor yang mempengaruhi ketepatan waktu pelaporan keuangan'. Jurnal Akuntansi Politeknik Sekayu, Volume 2. No. 1, hlm. 41-45.

Daud, et.al. (2014). 'The timeliness of financial reporting among jordanian companies: do company and board characteristics, and audit opinion matter?'. Asian Social Science, Volume 10. No. 13.

Dewi \& Jusia. (2013). 'Faktor-faktor yang mempengaruhi ketepatan waktu penyampaian laporan keuangan pada perusahaan real estate dan property yang terdaftar di bei'. Jurnal Akuntansi, Volume XVII. No. 03.

Dewi \& Pamudji (2013). 'Analisis faktor- faktor yang mempengaruhi ketepatan waktu penyampaian dan audit delay penyampaian laporan keuangan'. Journal of Accounting, Volume 2. No. 2.

Ebert, R.., \& Griffin, R. (2015). Pengantar bisnis: Edisi ke 10. Jakarta: Erlangga.

Ghozali, I. (2016). Aplikasi analisis multivariate dengan program IBM SPSS, Edisi 8, Semarang: Badan Penerbit Universitas Diponegoro.

Harahap, S. (2012). Teori akuntansi edisi revisi 2011. Jakarta: PT Rajagrafindo Persada.

Hastutik (2015). 'Pengaruh profitabilitas, likuiditas, struktur kepemilikan, ukuran perusahaan dan opini audit terhadap ketepatan waktu pelaporan keuangan perusahaan'. Jurnal akuntansi dan sistem teknologi informasi, Volume 11, hlm. 102111.

Henisa (2015). 'Pengaruh profitabilitas, likuiditas, ukuran perusahaan, reputasi kap dan opini auditor terhadap timeliness 
pelaporan keuangan (studi empiris pada perusahaan sektor infrastruktur, utilitas dan transportasi yang terdaftar di Bursa Efek Indonesia 2011-2013)'. Jom FEKON, Volume 2. No. 2, Oktober 2015.

Hilmi \& Ali. (2008). 'Analisis faktor-faktor yang mempengaruhi ketepatan waktu penyampaian laporan keuangan (studi empiris pada perusahaan-perusahaan yang terdaftar di BEJ)'. Simposium Nasional Akuntansi (SNA) XI. Pontianak, hlm. 1-26.

Imaniar \& Kurnia. (2016). 'Faktor- faktor yang mempengaruhi ketepatan waktu pelaporan keuangan perusahaan'. Jurnal Ilmu dan Riset Akuntansi, Volume 5.No. 6.

Iyoha. (2012). 'Company attributes and the timeliness of financial reporting in nigeria'. lecturer, departemen of accounting college of development studies, Covenant University P.M.B 1023 Ota, Nigeria.

Kadir (2011). 'Faktor-faktor yang berpengaruh terhadap ketepatan waktu pelaporan keuangan studi empiris pada perusahaan manufaktur di bursa efek jakarta'. Jurnal Manajemen dan Akuntansi, Volume XII. No. 1.

Mouna \& Anis . (2013). 'Financial reporting delay and investors behavior: evidence from tunisia'. Department of Finance Accounting, Volume 1, hlm. 57-67.

Muhardi. (2013). Analisis laporan keuangan proyeksi dan Vvluasi saham. Jakarta: Salemba.

Owusu \& Ansah. (2000). 'Timeliness of corporate financial reporting in emerging capital market: empirical evidence from the zimbabwe stock exchange'. Accounting and Business Research, Volume XXX. No. 3, hlm. 241-254.

Rahmawati. (2012). Teori akuntansi keuangan. Yogyakarta: Graha IImu.

Riswan \& Saputri. (2015). 'Pengaruh profitabilitas, ukuran perusahaan, debt to equity terhadap ketepatan waktu penyampaian laporan keuangan (Studi Pada Perusahaan Asuransi Yang Terdaftar Di BEI)'. Jurnal Akuntansi \& Keuangan, Vol. 6. No. 1, hlm. 111-127.
Sanjaya \& Wirawati. (2016). 'Analisis faktorfaktor yang mempengaruhi ketepatan waktu pelaporan keuangan pada perusahaan manufaktur yang terdaftar $\mathrm{Di}$ BEl'. E-Jurnal Akuntansi Universitas Udayana, Volume 15. No.1.

Suwardjono. (2011). Teori akuntansi perekayasaan laporan keuangan. Yogyakarta: BPFE-YOGYAKARTA. 